\title{
New distribution records of the critically endangered frog Telmatobufo bullocki Schmidt, 1952 (Anura: Calyptocephalellidae) in southern Chile
}

\author{
Felipe E. Rabanal ${ }^{1 *}$ and Virginia Moreno-Puig ${ }^{2}$ \\ 1 Universidad Austral de Chile, Instituto de Ciencias Ambientales y Evolutivas, Facultad de Ciencias, Casilla 567, Campus Isla Teja, Zip Code \\ 5090000, Valdivia, Chile. \\ 2 Massey University, Institute of Natural and Mathematical Sciences, Ecology, Behaviour \& Conservation Group, Private Bag 102-904, North Shore \\ Mail Centre, Albany, Auckland 0745, New Zealand. \\ * Corresponding author. E-mail: virginia.moreno@gmail.com
}

\begin{abstract}
In an effort to assess the current geographic distribution of the critically endangered frog Telmatobufo bullocki Schmidt, 1952, we conducted several field surveys in the Nahuelbuta mountain range in central-south Chile. We surveyed historic localities cited in the literature, and potential new localities in private forestry areas. Telmatobufo bullocki was found in six localities: four historic and two new. The discovery of new populations and the confirmation of the persistence of the species in at least four historic localities open new perspectives for the conservation of this threatened species.
\end{abstract}

The genus Telmatobufo Schmidt, 1952 comprises four species [T. australis Formas, 1972; T. bullocki Schmidt, 1952; T. ignotus Cuevas, 2010 and, T. venustus (Philippi, 1899)] distributed in the temperate forests of central and southern Chile $\left(35^{\circ} 30^{\prime}-41^{\circ} 10^{\prime}\right.$ S) (Cei 1962; Formas and Pugin 1979; Formas and Veloso 1982; Formas et al. 2001; Cuevas 2010; 2011). All Telmatobufo species are associated with cold mountain streams and their tadpoles are of the "mountain stream type", Group IV, sensu Orton (1953). The tadpoles are adapted to live and feed in fast flowing waters: they have a sucker-like oral disc to anchor themselves to submerged boulders (Figure 1E), strong paddle-shaped tails and a dorso-ventrally flattened body (Figures 1C and 1D) (Formas 1972; Díaz et al. 1983; Formas 1988; Lavilla 1988). The adults have well-developed inter-digital webbing between their toes (Figure 1B), and Péfaur (1971) noted that captive $T$. bullocki could remain completely submerged for more than one and a half hours, suggesting great affinity with aquatic environments.

Currently Telmatobufo bullocki (Figure 1A) is considered one of the most endangered species of amphibians in Chile and the world. It has been classified as critically endangered by the IUCN (2012), and listed as $5^{\text {th }}$ of the 100 most Evolutionarily Distinct and Globally Endangered (EDGE) amphibians (http://www.edgeofexistence.org), based on EDGE Scores sensu Isaac et al. (2007). This ranking takes into account the level of threat and phylogeny of the species, where the taxa with major conservation problems and a distinctive evolutionary history are given priority in conservation action plans. More recently, the species was also listed as one of the 100 most endangered species in the world, in a list which includes both animals and plants (Baillie and Butcher 2012).

Since its original description in 1952 by Schmidt, T. bullocki has been recorded in at least five localities on the eastern slopes of the Nahuelbuta mountain range, and in six localities on the western slopes. The species was also recorded in Quirihue (Ñuble Province, Biobío Region), approximately $150 \mathrm{~km}$ north of the Nahuelbuta range (Escobar et al. 2005). A putative third population north of the Nahuelbuta range was reported by Donoso et al. (2010) in a small protected area of a Maulino deciduous forest in Los Queules National Reserve, Maule Region. However, Cuevas (2010) considered this population to be the newly described Telmatobufo ignotus, and described this area as the type locality of the species. However, it is possible that the Telmatobufo population in Quirihue corresponds to T. ignotus instead of T. bullocki, as it is geographically closer to Los Queules National Reserve than the Nahuelbuta range. Most records of T. bullocki in the literature date from the 1960 s to the 1990 s, and the species was considered lost for several years as many surveys conducted in the Nahuelbuta area by different specialist groups failed to find any specimens.

In an effort to assess the current status of historic T. bullocki populations, and to find new localities, we conducted several field surveys between December 2008 and December 2012. We surveyed several historic locations, and previously un-surveyed localities within the Nahuelbuta range, mainly in private forestry areas. Surveys were conducted under permit number 13-2011 IX, issued by Departamento de Áreas Silvestres Protegidas, Región de la Araucanía, of the Corporación Nacional Forestal, CONAF, and permit number 6977 from Servicio Agrícola y Ganadero, SAG. Surveys were conducted during daylight hours (looking under logs, fallen tree trunks and other possible refuges), and nocturnally (looking for active animals using a head-torch). We surveyed both aquatic habitat (in search of tadpoles and breeding adults), and terrestrial habitat adjacent to streams. Animals were identified as T. bullocki by visual inspection of characteristic features such as their yellow inter-ocular spots and their dorsal and paratoid gland pattern in adults (Schmidt 
1952; Formas et al. 2001), and the oral disc (a suckerlike mouth, Figure 2E) and flattened bodies in tadpoles (Formas 1988). Due to its high risk conservation status we did not collect any voucher specimens, but all encountered individuals were photographed. Photographs have been deposited at Herpetological Collection of Universidad de Concepción, Chile (MZUC 34191).

We found specimens of T. bullocki at six localities (Figure 2, Table 1). Four of these correspond to historic (Elicura, Estero La Cueva, Caramávida, and Estero Los Lleulles), and two are new localities for this species: Río Butamalal, $19 \mathrm{~km}$ southeast from Cañete $\left(37^{\circ} 50^{\prime} \mathrm{S}, 73^{\circ} 10^{\prime}\right.$ W; $424 \mathrm{~m}$ asl); and Predio Chivilingo (Private Conservation
Area), $5.4 \mathrm{~km}$ southeast from Lota $\left(37^{\circ} 07^{\prime} \mathrm{S}, 73^{\circ} 06^{\prime} \mathrm{W}\right.$; $363 \mathrm{~m}$ asl). Despite several surveys, the species was not found at some historic locations: Ramadillas, Vanerías and Estero Cabrerías (Parque Nacional Nahuelbuta), and Vegas Blancas. The newly discovered population in Río Butamalal is in a privately owned large patch of mature and secondary native forest, while the population in Chivilingo is in a very small privately owned secondary native forest patch surrounded by exotic forestry plantation.

Telmatobufo bullocki has been considered a rare species since its description. Only a few specimens have ever been collected, and even Dr. Bullock (after whom the species is named) only encountered the species on three occasions
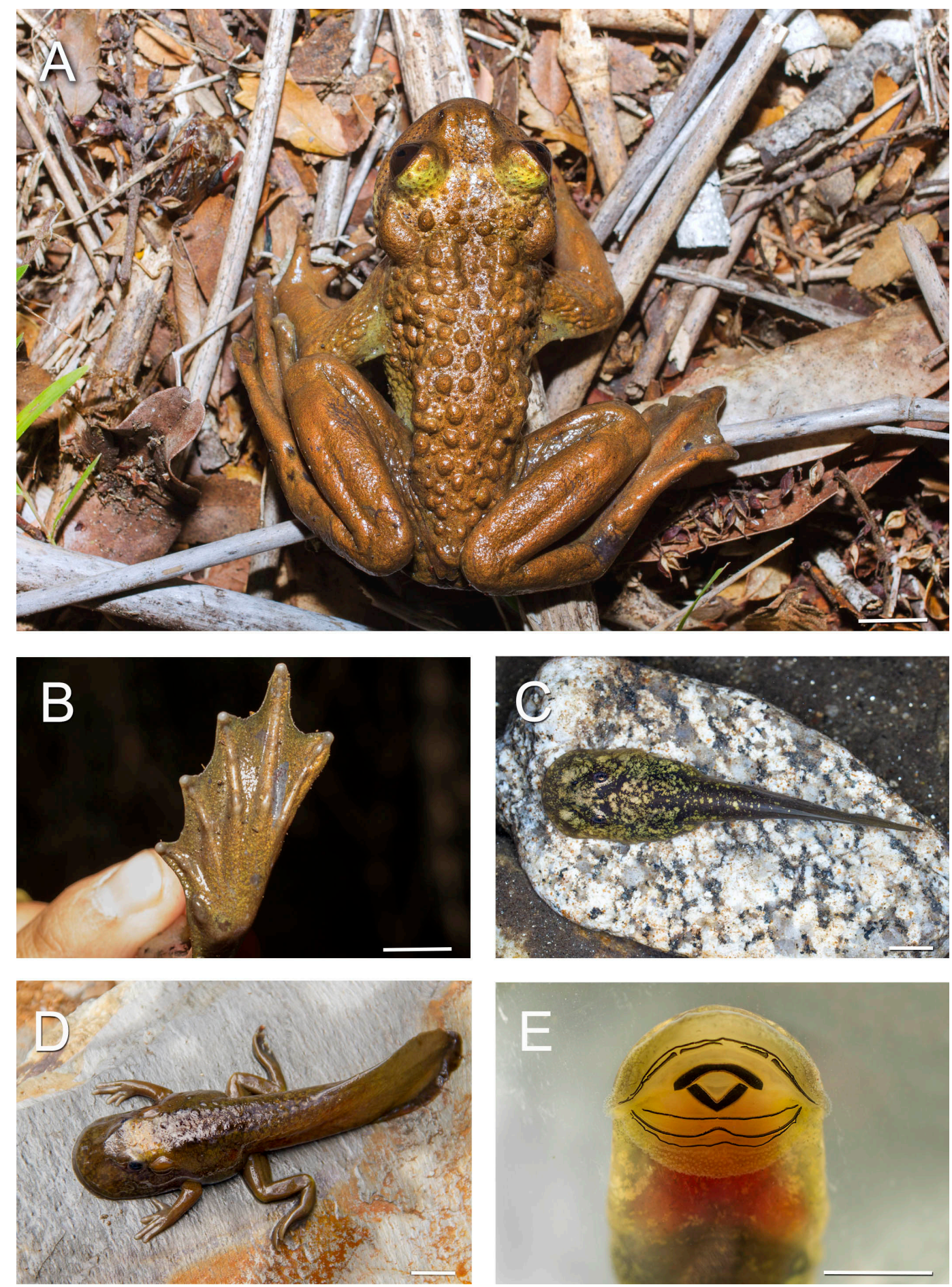

FIGURE 1. Specimens of T. bullocki from Butamalal River in the Nahuelbuta mountain range. A) Adult male, B) Inter-digital webbing between the toes of the adult specimen, C) Tadpole (Stage 27 Gosner), D) Pre-metamorphic specimen (Stage 38 Gosner), E) Sucker-like oral disc of the tadpole (Stage 26 Gosner). Scale bar $=1 \mathrm{~cm}$. 
TABLE 1. T. bullocki records including historic and new records ( ${ }^{*}$ Historic localities corroborated in the field; ${ }^{* *}$ New localities). Some close localities are represented under the same label. Some references only give locality names, no coordinates provided.

\begin{tabular}{|c|c|c|c|c|}
\hline LABEL & LOCALITY NAME & LATITUDE & LONGITUDE & REFERENCE \\
\hline 1 & Lota & - & - & Venegas (1975) \\
\hline $2^{* *}$ & Predio Chivilingo & $37^{\circ} 07^{\prime} \mathrm{S}$ & $73^{\circ} 06^{\prime} \mathrm{W}$ & This publication \\
\hline 3 & Ramadillas & $\begin{array}{l}- \\
- \\
-\end{array}$ & $\begin{array}{l}- \\
- \\
-\end{array}$ & $\begin{array}{l}\text { Donoso-Barros (1972) } \\
\text { Formas and Veloso (1982) } \\
\text { Formas et al. (2001) }\end{array}$ \\
\hline \multirow[t]{2}{*}{$4^{*}$} & Caramávida & $\begin{array}{l}- \\
- \\
37^{\circ} 42^{\prime} \mathrm{S}\end{array}$ & $\begin{array}{l}- \\
73^{\circ} 12^{\prime} \mathrm{W}\end{array}$ & $\begin{array}{l}\text { Formas and Veloso (1982) } \\
\text { Formas et al. (2001) } \\
\text { This publication }\end{array}$ \\
\hline & Rucapehuén & $37^{\circ} 40^{\prime} \mathrm{S}$ & $73^{\circ} 25^{\prime} \mathrm{W}$ & Nuñez and Formas (2000) \\
\hline $5^{*}$ & Estero La Cueva & $\begin{array}{l}37^{\circ} 40^{\prime} \mathrm{S} \\
37^{\circ} 44^{\prime} \mathrm{S}\end{array}$ & $\begin{array}{l}73^{\circ} 25^{\prime} \mathrm{W} \\
73^{\circ} 08^{\prime} \mathrm{W}\end{array}$ & $\begin{array}{l}\text { Formas (1988) } \\
\text { This publication }\end{array}$ \\
\hline $6^{* *}$ & Río Butamalal & $37^{\circ} 50^{\prime} \mathrm{S}$ & $73^{\circ} 10^{\prime} \mathrm{W}$ & This publication \\
\hline 7 & Estero Cabrerías & - & - & Cei (1962) \\
\hline $8^{*}$ & Elicura & $37^{\circ} 54^{\prime} \mathrm{S}$ & $73^{\circ} 13^{\prime} \mathrm{W}$ & $\begin{array}{l}\text { Sanfeliu (1969) } \\
\text { This publication }\end{array}$ \\
\hline 9 & $\begin{array}{l}\text { Vanerías } \\
\text { (Parque Nacional Nahuelbuta) }\end{array}$ & - & - & Péfaur (1971) \\
\hline \multirow[t]{2}{*}{10} & $\begin{array}{l}\text { Estero Cabrerías } \\
\text { (Parque Nacional Nahuelbuta) }\end{array}$ & - & - & Péfaur (1971) \\
\hline & Vegas Blancas & - & - & Cei (1962) \\
\hline 11 & Vegas de Rucapillán & - & - & Péfaur (1971) \\
\hline $12^{*}$ & Estero Los Lleulles & $\begin{array}{l}- \\
- \\
37^{\circ} 47^{\prime} \mathrm{S}\end{array}$ & $\begin{array}{l}- \\
- \\
72^{\circ} 48^{\prime} \mathrm{W}\end{array}$ & $\begin{array}{l}\text { Péfaur (1971) } \\
\text { Duellman (1975) } \\
\text { This publication }\end{array}$ \\
\hline
\end{tabular}

during his numerous trips to Nahuelbuta (Bullock 1954). Sightings that followed its discovery were scarce, and in the IUCN Red List population assessment the authors reported that 'extensive fieldwork by several herpetologists within the range of this species from 1992-2002 turned up only a single adult (in 2002)' (Veloso et al. 2010). This report generated the general idea that the species was not only rare but on the brink of extinction. However, in our surveys we detected T. bullocki at six localities (Figure 2 , Table 1). Nevertheless, this increase in detectability is likely to reflect our improved ability to find them rather than a true increase in numbers. It is now recognized that previous field surveys failed to detect the species, in part, because they were exclusively focused on the aquatic environments (J. C. Ortiz, pers. comm.), while our surveys showed that the adults can be found in terrestrial habitat far from streams during the non-breeding season (unpublished data). Also, most efforts were focused inside the Nahuelbuta National Park, excluding most of the areas surveyed by us, possibly because of restricted access due to private ownership of forestry land.

We confirm that this species is rare, even now that we have better knowledge of its habitat use. The fact that the species was not found at some of its historic localities is of most concern, but it comes as no surprise. The Nahuelbuta range has suffered a dramatic change during the past century, where native forest has been extensively cleared and replaced first by cattle and agriculture, and then by exotic forestry plantations of pine (Pinus radiata) and eucalyptus (Eucalyptus globulus), which today covers nearly 70\% of the area (CONAF 2008; Wolodarsky-Franke and Díaz Herrera 2011). Some of the historic localities are covered by these exotic plantations, and others are only small fragments of what once was a continuous native forest. Of special concern is the apparent disappearance of the species from the Nahuelbuta National Park, the

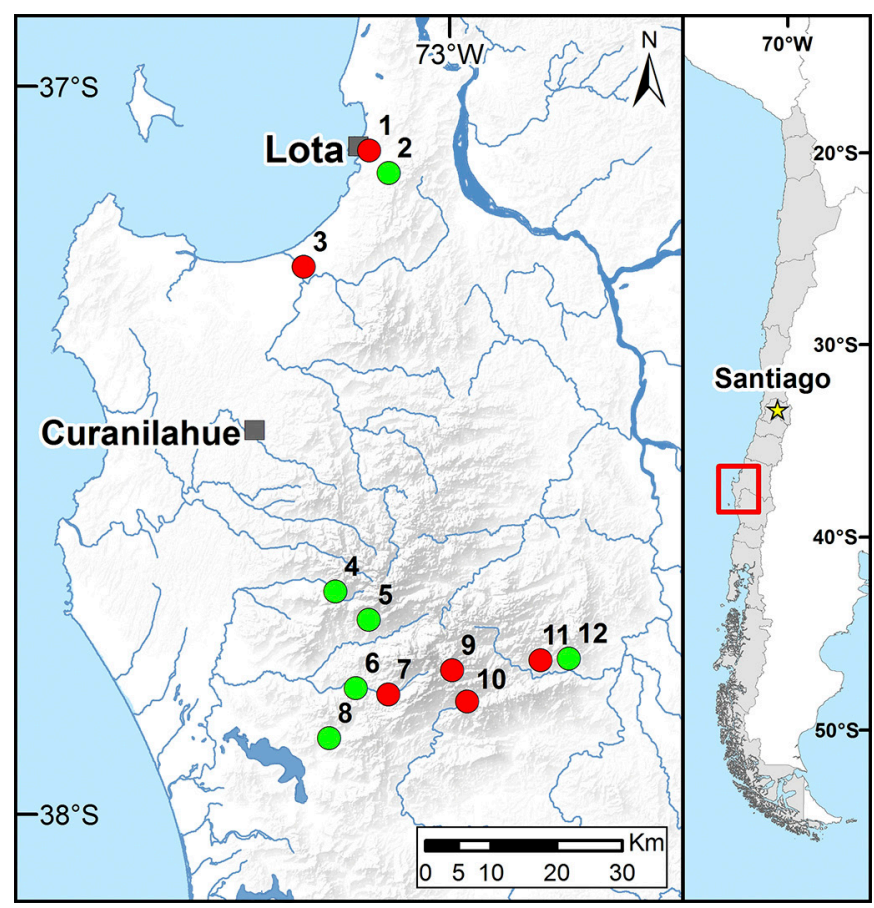

FIGURE 2. Distribution of T. bullocki in the Nahuelbuta mountain range. Green dots are localities where we found the species recently. Red dots are historic localities where the species has not been found recently. Numbers correspond to labels in Table 1.

only state protected area where the species was thought to be present. Despite several herpetological surveys, the species was last seen inside the park during the 1960s (Péfaur 1971). This is of great concern as the habitat has remained untouched, and there is no obvious evidence for this decline. Although we cannot rule out the possibility that the species is present, but undetected on our surveys, it is likely that at least some historic populations no longer exist. On the other hand, some historic populations in localities that have been under significantly more pressure 
from forestry development still persist (e.g. Los Lleulles), showing that the species has at least some degree of resilience to habitat change and disturbance.

Most of the localities where we found the species are currently owned by private forestry companies; and we found T. bullocki in both native forest and mature pine plantation. Some of these areas, particularly those comprised of mature native forest are already considered of high conservation value (e.g. Quebrada de Caramávida), and receive active protection from forestry companies. However, populations that occur in small native fragments, and individuals living in pine plantations face imminent risk from timber industry activities, especially clearcutting operations. Consequently, it is critical to involve the private owners and forestry companies as main stakeholders in the conservation of T. bullocki populations. The results we present here represent the most thorough and updated account of the distribution of this species and represent one of the first steps towards its conservation. With our improved knowledge about its current distribution, we can now focus on the study of the natural history, ecology and behavior of the species, to promote the in-situ conservation of the populations and assess the need for ex-situ conservation if natural conditions are not likely to provide suitable habitat in the long term.

Acknowledgments: The authors thank CONAF, Arauco S.A. and Bioforest S.A. for access permits, D. Alarcón, C. Aguayo, T. Elgueta, E. Flores, B. Álvarez and C. Elton, for their enthusiastic assistance in the field and P. J. Bishop for comments on the manuscript. This work was partially funded by The Mohamed bin Zayed Species Conservation Fund, the EAZA Amphibian Conservation Fund and the Rufford Small Grants Foundation.

\section{Literature Cited}

Baillie, J.E.M. and E.R. Butcher. 2012. Priceless or Worthless? The world's most threatened species. London: Zoological Society of London, United Kingdom. 124 pp.

Bullock, D. 1954. Una especie nueva de rana de Nahuelbuta. Boletín del Jardín Zoológico de Concepción, Chile 1(2): 1-3.

Cei, J.M. 1962. Batracios de Chile. Santiago: Editorial Universidad de Chile. $128 \mathrm{pp}$.

CONAF 2008. Catastro y Evaluación de los Recursos Vegetacionales Nativos de Chile. Santiago, Chile: Corporación Nacional Forestal. Accessible at http://territorial.sinia.cl/portal/descargas.php. Captured on 24 May 2011.

Cuevas, C. 2010. A new species of Telmatobufo (Schmidt 1852) (Anura, Calyptocephalellidae) from a remnant of the Maulino Forest, central Chile. Gayana 74: 102-112.

Cuevas, C. 2011. New geographic records of Telmatobufo australis Formas, 1972 (Amphibia: Anura: Calyptocephallelidae) in southern Chile. Boletín de Biodiversidad de Chile 5: 28-35.

Díaz, N., M. Sallaberry and H. Núñez. 1983. The tadpole of Telmatobufo venustus (Anura: Leptodactylidae) with a consideration of generic relationships. Herpetologica 39: 111-113.

Donoso, D.S., C. Correa Q., P. Henriquez, N.F. Lagos and M.A. Méndez. 2010. Amphibia, Anura, Calyptocephalellidae, Telmatobufo bullocki
Schmidt, 1952: Distribution extension, habitat use and geographic distribution map. Check List 6(2): 298-300.

Donoso-Barros, R. 1972. Contribución al conocimiento del género Aruncus Phillippi. Boletín de la Sociedad de Biología de Concepción 44: 109-116.

Duellman, W.E. 1975. Collection specimen Telmatobufo venustus $[=T$. bullocki). Catalogue number 161438, in: Kansas University Herps Collection. Accessible at http://collections.nhm.ku.edu/HerpsWeb. Captured on 02 May 2012.

Escobar, M.A.H, C.F, Estades, M. Falcy and M.A. Vukasovik 2005. Telmatobufo bullocki (Bullock's Frog) [Geographic Distribution]. Herpetological Review 36(1): 77.

Formas, J.R. 1972. A second species of Chilean frog genus Telmatobufo (Anura: Leptodactylidae). Journal of Herpetology 6(1): 1-3.

Formas, J.R. 1988. The tadpole of Telmatobufo bullocki (Anura: Leptodactylidae). Herpetologica 44: 458-460.

Formas, J.R. and E. Pugin. 1979. New observations of Telmatobufo australis (Anura: Leptodactylidae) in Southern Chile. Journal of Herpetology 13: 359-361.

Formas, J.R. and A. Veloso. 1982. Taxonomy of Bufo venustus Philippi, 1899 (Anura: Leptodactylidae) from Central Chile. Proceedings of Biological Society of Washington 95: 688-693.

Formas, J.R., J.J. Nuñez and L.M. Brieva. 2001. Osteología, taxonomía y relaciones filogenéticas de las ranas del género Telmatobufo (Leptodactylidae). Revista Chilena de Historia Natural 74: 365-387.

Isaac, N.J.B., S.T. Turvey, B. Collen, C. Waterman and J.E.M. Baillie. 2007. Mammals on the EDGE: Conservation priorities based on threat and phylogeny. Plos One 2(3): e296.

IUCN 2011. IUCN Red List of Threatened Species. Version 2011.2. Accessible at http://www.iucnredlist.org/. Captured on 16 October 2012.

Lavilla, E. 1988. Lower Telmatobiinae (Anura: Leptodactylidae): Generic diagnoses based on larval characters. Occasional Papers of the Museum of Natural History, the University of Kansas 124: 1-19.

Nuñez, J.J. and J.R. Formas. 2000. Evolutionary history of the Chilean frog genus Telmatobufo (Leptodactylidae): an immunological approach. Amphibia-Reptilia 21: 351-356.

Orton, G.L. 1953. The systematics of vertebrae larvae. Systematics Zoology 2: 63-75.

Péfaur, J. 1971. Nota sobre Telmatobufo bullocki (Anura, Leptodactylidae). Boletín del Museo de Historia Natural de Chile 32: 723-725.

Sanfeliu, I. 1969. Collection specimen Telmatobufo bullocki, Catalogue number A-78829, in: MCZBASE: The Database of the Zoological Collections, Museum of Comparative Zoology, Harvard University. Accessible at http://mczbase.mcz.harvard.edu/guid/ MCZ:Herp:A-78829. Captured on 02 May 2012.

Schmidt, K.P. 1952. A new leptodactylid frog from Chile. Fieldiana Zoology 34: 11-15.

Veloso, A., H. Núñez and R. Formas. 2010. Telmatobufo bullocki, in: IUCN 2012. IUCN Red List of Threatened Species Version 2012.2. Accessible at http://www.iucnredlist.org/. Captured on 03 March 2013.

Venegas S., W. 1975. Los cromosomas de Aruncus venustus (Philippi) 1899 (=Telmatobufo bullocki Schmidt, 1952). Boletín Sociedad de Biología de Concepción 49: 71-77.

Wolodarsky-Franke, A. and S. Díaz Herrera. 2011. Cordillera de Nahuelbuta. Reserva Mundial de Biodiversidad. Valdivia: WWF. 56 pp.

RECEIVED: September 2013

ACCEPTED: December 2013

PUBLISHED ONLINE: May 2014

EDITORIAL RESPONSIBILITY: Ross MacCulloch 